\title{
Element composition of a vegetable composition and extract of dry, obtained on its basis, with sedative activity
}

\author{
C Maria G. Tokareva, ${ }^{1{ }^{+}}$Elena V. Chuparina, ${ }^{2}$ Victor V. Vandyshev, ${ }^{3}$ \\ Elena V. Borisenko, ${ }^{1}$ and Marina A. Dzhavakhyan ${ }^{1}$ \\ ${ }^{1}$ All-Russian Research Institute of Medicinal and Aromatic Plants. \\ Green St., 7. Moscow, 117216.Russia.E-mail:t-mehri@yandex.ru \\ ${ }^{2}$ Vinogradov Institute of Geochemistry SB RAS. Favorsky St., 1A. Irkutsk, 664033. Russia. \\ ${ }^{3}$ Peoples' Friendship University of Russia. Miklouho-Maclay St., 6. Moscow, 117198. Russia.
}

\begin{abstract}
Keywords: herbal composition, dry extract, trace elements, X-ray fluorescence analysis.
\end{abstract}
*Supervising author; ${ }^{+}$Corresponding author

\begin{abstract}
Currently, the search for promising sources of drugs for the prevention and treatment of neurosis is one of the promising areas of pharmaceutical technology. Stressful factors, lack of rest, irregular work schedule have a significant impact on the modern human body and represent a serious medical and social problem. According to doctors and patients, the most appropriate treatment is sedative drugs of plant origin, which reduce the response to external stimuli.

The herbal composition contains a complex of biologically active substances of plants: motherwort, St. John's wort, lemon balm and thyme in a ratio of $4: 2.5: 2.5$, which determine their therapeutic effect. The liquid and dry extracts obtained from this collection are original in composition. The quality assessment of the studied objects was carried out according to the main active substances - flavonoids. However, it is reliably known that the whole complex of substances that make up the plant composition has pharmacological activity.

In this regard, the purpose of this study was a comparative study of the microelement composition of the plant composition and dry extract, designed to create a medicinal product with a sedative effect.

When comparing the results of determining the content of elements in the plant composition (raw materials) and dry extract from it, a number of elements were identified that were well extracted using the proposed technology from the raw materials with the used extractant: $\mathrm{K}, \mathrm{Mg}, \mathrm{Br}, \mathrm{Zn}, \mathrm{Cu}, \mathrm{Cl}, \mathrm{P}, \mathrm{S}$. According to the content heavy metal dry extract is significantly inferior to those in the plant composition.
\end{abstract}

\section{References}

[1] A. Skalnyy. Microelements: vitality, health, longevity. Litres. 2017. (russian)

[2] L.I. Gubareva et al. Combined effect of hypo-and hypermicroelementoses on the functioning of the cardiovascular, endocrine systems and the level of anxiety in adolescents. Human Ecology. 2017. No.8. P.29-35. (russian)

[3] V.A. Popova, A.A. Kozhin, Yu.I. Megid. Microelementoses and children's health problems. Pediatrics. Magazine them. G.N. Speransky. 2015. Vol.94. No.6. P.140-144. (russian)

[4] E. Dvoryankova et al. Prospects for the use of combined drugs containing potassium and magnesium. Doctor. 2012. No.8. P.49-51. (russian)

[5] O.A. Shavlovskaya. Therapy of anxiety conditions with herbal preparations. Effective Pharmacotherapy. 2016. No.25. P.62. (russian)

[6] O.N. Shplis, N.E. Kolomiyets, N.Yu. Abramets, E.B. Daybova, R.A. Bondarchuk, A.A. Maryin, I.M. Smolyakova, S.N. Avdeenko. Elemental composition of wild horned lamb and cultivated in the subtaiga zone of Western Siberia. Chemistry of plant raw materials. 2020. No.1. P.237-244. URL: http://journal.asu.ru/cw/article/view/6124

[7] P. Kalny et al. Determination of selected microelements in polish herbs and their infusions. Science of the total environment. 2007. Vol.381. No.1-3. P.99-104.

[8] M. Zembala et al. Effect of selenium on macro-and microelement distribution and physiological parameters of rape and wheat seedlings exposed to cadmium stress. Plant and Soil. 2010. Vol.329. No.12. P.457-468.

[9] T.M. Derkach, V.G. Khomenko. Essential and toxic microelements in the medicinal remedy hyperichi herba by different producers.Research Journal of Pharmacy and Technology. 2018. Vol.11. No.2. P. 466474. 
[10] G. Bakonyi, P. Nagy, I. Kádár. Long-term effects of heavy metals and microelements on nematode assemblage. Toxicology Letters. 2003. Vol.140. P.391-401.

[11] N.I. Steblevskaya et al. Microelement composition of some species of Lespedeza, Caragana (Fabaceae) and Patrinia (Valerianaceae) of the Far East. Rastitel'nye Resursy. 2009. Vol.45. No.3. P.102-111.

[12] Li L. et al. Calcium, magnesium and microelement uptake as affected by phosphorus sources and interspecific root interactions between wheat and chickpea. Plant and Soil. 2004. Vol.261. No.1-2. P.29-37.

[13] L.R. Vardanyan, R.L. Vardanyan. Element Composition of Barberry (Berberus L.) and Deaf Nettle (Lamium Album L.) Leaves. Chemistry and Biology. 2014. No.1. P.28-31

[14] E. Suchowilska et al. A comparison of macro-and microelement concentrations in the whole grain of four Triticum species. Plant, Soil and Environment. 2012. Vol.58. No.3. P.141-147

[15] J. Tasi. Heavy metal, macro-and microelement content of grass species and dicotyledons. Acta Agronomica Hungarica. 2005. Vol.53. No.3. P.349-352.

[16] A. Wallace et al. Comparison of the effects of high levels of DTPA and EDDHA on microelement uptake in bush beans. Communications in Soil Science and Plant Analysis. 1976. Vol.7. No.1. P.111116.

[17] Patent 2683643 Russian Federation, IPC A61K 36/53, A61K 36/533, A61K 36/38, B01D 11/02, A61P9 / 02, A61P 25/20 A method for producing an aqueous-alcoholic extract of medicinal plants with sedative and hypotensive action. Javakhyan M.A. [and etc.]; applicant and patentee FGBNU VILAR. No. 2018118635, declared 05/22/2018, publ. 04/01/2019. Bull. No.0 . 